\title{
Determinants of credit default swap \\ (CDS) spreads in Latin America: \\ An empirical analysis of corporate debt in public and private companies
}

\author{
Edgardo Cayón \\ Professor finance, CESA Business School \\ Colombia \\ ecayon@cesa.edu.co
}

Juan Manuel Perilla

Colombia

jperilla@fidubogota.com

Abstract. In this article we have examined the effects of the common determinants of credit quality such as cash, debt, and tangibility on CDS spreads in Latin America. Our sample consists of 50 Latin American companies, while the period under consideration is between 2006 and 2016. Using the panel regression model in which we have controlled for year and company effects, we have found that certain proxies for cash, debt, and tangibility could explain the variation in CDS spreads in publicly traded companies, but not in the case of private companies that trade bonds at international markets. For private companies in Latin America, none of the common determinants for spreads $8330.2018 / 11-4 / 4$ were statistically significant. For public companies, we have found that the most statistically significant proxies for cash, debt, and tangibility explaining the variation in CDS spreads are retained earnings, total debt/total assets, inventories, and fixed assets. Our results show that in the case of private companies of Latin America, the common CDS spreads determinants found in literature do not help explaining the variation in spreads.

Keywords: Latin American bonds, corporate debt, determinants, panel regression, public companies, private companies.

JEL Classification: G3, G32

\section{INTRODUCTION}

In the last few decades, global growth has mainly been driven by emerging market economies. In this context, corporate debt issues have become an important source of financing for emerging multinational companies located in Latin America. Although Latin American debt market is quite small when compared to the debt markets of developed countries, the former has been growing steadily in the last few years. A 
recent study by the Central Bank of Spain shows that from 2015 to 2016, the corporate debt market in Latin America increased from USD 61 billion to USD 140 billion, which is an increase of 81\% (Fuertes et al., 2016). Therefore, this increase in debt financing by companies in the region poses an interesting question concerning the drivers behind it

There have been studies addressing the question of emerging market bond determinants in recent years. Some previous studies on emerging market bond returns were concerned mainly with the characteristics of bond returns as investment vehicles. These studies are from more than two decades ago and they are suggesting that emerging market bonds, besides being highly correlated with equity markets, also exhibited the same statistical characteristics of equities such as negative skewness, and that this was especially true in the times of financial crisis (Bekaert \& Harvey, 1997; Erb, Harvey, \& Viskanta, 1999). However, there is not that much research on the determinants of yields and on the probability of sovereign debt default in case of emerging markets. In the specific case of emerging market sovereign spread bonds, the most relevant determinants are correlated with different macroeconomic indicators such as investment to GDP ratio, exports to GDP, and current account to GDP etc ${ }^{1}$.

\section{LITERATURE REVIEW}

\subsection{Bonds determinants}

For corporate bond determinants, most of the studies have focused on developed markets. Hotchkiss and Jostova (2007) used a comprehensive dataset of US corporate bonds in order to find the determinants for bond trading in the USA. In their study, they used measures such as the size of the issue, the age of the bond, the absolute value of bond returns, the interest rate, and equity market return shocks. The authors found that when determining the trading volume of corporate bonds, the most relevant determinants were issue size and age, and that the issues of public companies with actively traded stocks were more liquid on average than those issues from private companies. A recent study by Massa \& Žaldokas (2014) shows evidence that issues of corporate debt in international markets have lower yields than issues that merely focus on their domestic counterparts. To test their hypothesis, the authors developed a measure called "international taste," which is computed as the percentage of ownership of a particular issue by international investors versus domestic ones. However, they also used measures such as maturity and the size of the issue, while at the same time controlling for firm characteristics such as tangibility, profitability, debt, and firm size, which are common determinant measures in leverage studies².

Regarding the determinants of corporate bond yields in emerging markets, there are a few country studies on the subject. For example, Šević and $\mathrm{Lu}$ (2013) found that for China, corporate bond yields were generally consistent with the "sovereign ceiling rule," which states that no corporation is more creditworthy than a sovereign bond from its country of origin. In this paper, the authors used a common control bond and firm variables but additionally controlled for volatility for both bonds and stocks. CheYahya, Abdul-Rahim, and Mohd-Rashid (2016)found that for corporate spreads in Malaysia, bond-specific variables such as bond maturity, coupon payment, and trading frequency were statistically significant, as well as certain firm-specific variables such as the debt to equity ratio and the return on equity ratio. In the case of Tunisia, Hammami and Bahri (2016) use the French-Fama three-factor model to explain corporate

\footnotetext{
1 See for example:(Balazs \& Ivaschenko, 2013; Calvo \& Reinhart, 1999; Dittmar \& Yuan, 2008; Dungey, Fry, GonzalezHermosillo, \& Martin, 2005; Edwards, 1986; Eichengreen \& Mody, 1998; Ferrucci, 2003; Martinez, Terceño, \& Teruel, 2013; Reinhart \& Rogoff, 2008).

${ }^{2}$ See for example: (Rajan \& Zingales, 1995).
} 
bond returns in Tunisia, and found that certain cross-sectional characteristics such as ratings had more explanatory power in explaining returns than the betas from the three-factor model.

\subsection{Firm characteristics}

Firm characteristics have been used frequently to predict corporate bond default. Altman (2005) proposes a model for predicting bankruptcy in emerging markets that uses accounting measures such as working capital/total assets, retained earnings/total assets, operating income/total assets and book value of equity/total liabilities. In another study by Ge and Liu (2015), in which the authors measure the impact of corporate social responsibility on corporate bond yields, the authors use bond a number of variables such as: ratings, maturity, covenants, issue size, issuer size, return on assets (ROA), leverage and whether the firm was audited by one of the big 4 firms. Ge and Kim (2014) examine the relationship between real management earnings and corporate bond yields by using bond-specific variables such as yield spread, issue size, maturity, ratings, and bond provisions, and other firm-specific characteristics such as size, market to book ratio, interest coverage, profitability, and leverage. Huang and Petkevich (2016) examine the relationship between institutional ownership and its effect on bond yields. The authors used similar variables as the afore-mentioned studies, but they explored other bond-specific variables such as CDS spreads and bond prices, and other firm-specific variables such as the beta of the firm, and stock returns as proxies for risk. Finally, in a recent paper by Douglas, Huang, and Vetzal (2016), the authors explore the effects of cash flow volatility using different proxies such as cash flow/firm value, cash flow/book assets and cash flow/debt outflow. In the case of European corporate spreads, Pieterse-Bloem, Qian, Verschoor, and Zwinkels (2016), by using a time-varying asset-pricing framework, found that fixed country factors dominated industry-specific factors as a source of variation in corporate spreads. Another study by Van Landschoot (2008) found that the dynamics between Euro and US corporate spreads were explained by liquidity, and that US corporate spreads were more affected by changes in US government yields, and that Euro Spreads were, in turn, affected by changes in US corporate spread.

Therefore, the purpose of our paper is to find which determinants have the greatest impact on CDS spreads in Latin America. By using panel data on selected corporate Latin American dollar bond issues, we will identify which bond-specific variables and firm-specific characteristics are statistically significant in determining bond yields. In this way, identifying the relevant determinants of CDS can help issuers in the region to identify the relevant factors that affect the cost of financing within the region. Using a sample that consists of 50 Latin American companies for the period under consideration between 2006 and 2016, we used a panel regression model in which we controlled for year and company effects. The choice of model is based on the before mentioned studies on the subject, and because this type of specification allow us to control for the fact that the companies in the sample can be either private or public. A panel regression specification also allow us to control for the fact that the companies in the sample belong to different economic sectors. The remainder of this paper is structured as follows. In Section 3, we describe the data and the panel regression model. In Section 4, we discuss the empirical results obtained from the model and carry out some robustness tests, and, finally, in Section 5, we conclude.

\section{METHODOLOGY}

In order to select our sample of Latin American corporate bonds, we focused on the most liquid issues in the market. To select the issues that conformed to the sample, we used the transaction reports of the principal Latin American brokerage firms that hold these types of assets in their portfolios. We only included bullet bonds in our sample to avoid the valuation problems inherent with callable and convertible bonds. Another criterion was that the bonds had to be issued in USD and traded internationally. After 
using these parameters as our selection criteria, the final sample consisted of 50 Latin American companies for the period under consideration between 2006 and 2016. Since each issuer had several bond issues with different maturities, we aggregated each company's bond issues in a weighted average value portfolio using the market prices recorded at the end of the fiscal year. By employing this approach, we were able to obtain a proxy for each company's total annual return in our sample using market prices.

We extracted the CDS data and the financial data (see Table 1) for each issuer from Bloomberg. We compiled the following financial information using balance sheets and income statements converted to USD. We compiled financial information to calculate the following financial indicators that previous authors have used in other studies on bond determinants 3 . Our methodology is similar to that proposed by Douglas et al. (2016) in which they use a series of commonly used financial indicators to proxy for cash flow volatility.

Table 1 reports the descriptive statistics for the independent and explanatory variables in the sample. This sample contains the financial data of 50 Latin American companies for the period under consideration between 2009 and 2016 that trade bullet bonds issued in USD on international markets. Since each issuer has several bond issues with different maturities, we aggregated each company's bond issues in a weighted average value portfolio using the market prices recorded at the end of the fiscal year in order to obtain the yield from the previous year. By employing this approach, we were able to obtain the variable called "bond yield," which acts as a proxy for market expectations. We obtained all the financial data from Bloomberg and converted the figures to USD in order to control for foreign exchange fluctuations.

Table 1

Descriptive statistics

\begin{tabular}{|c|c|c|c|c|c|c|c|}
\hline & CDS & FCF & $\begin{array}{l}\text { Working } \\
\text { Capital }\end{array}$ & EBIT & RetainedEarnings & $\begin{array}{c}\text { Total current } \\
\text { liabilities }\end{array}$ & $\begin{array}{c}\text { Total debt } \\
\text { to total } \\
\text { assets }\end{array}$ \\
\hline Mean & 243,77 & 694,49 & 29322,81 & 4327,25 & 1489,13 & 34966,70 & 0,33 \\
\hline Median & 203,00 & 300,81 & 1182,74 & 698,59 & 881,74 & 2781,79 & 0,31 \\
\hline Maximum & 1044,00 & 57602,78 & 1264700,00 & 69516,32 & 59228,79 & 1428700,00 & 0,85 \\
\hline Minimum & 17,00 & $-52463,10$ & $-10227,72$ & $-2232,30$ & $-73439,42$ & 137,64 & 0,00 \\
\hline Std. Dev. & 167,44 & 7008,27 & 169950,10 & 12228,68 & 10435,50 & 189319,50 & 0,13 \\
\hline Skewness & 1,90 & 2,20 & 6,89 & 4,13 & $-2,29$ & 6,95 & 0,80 \\
\hline Kurtosis & 7,84 & 47,36 & 48,78 & 19,53 & 33,13 & 49,62 & 4,67 \\
\hline \multirow[t]{2}{*}{ Observations } & 210 & 218 & 204 & 207 & 218 & 207 & 222 \\
\hline & $\begin{array}{c}\text { Free cash } \\
\text { flow to debt }\end{array}$ & PPE & $\begin{array}{l}\text { Total debt } \\
\text { to tangible } \\
\text { assets }\end{array}$ & Inventories & $\begin{array}{l}\text { Total liabilities to } \\
\text { tangible assets }\end{array}$ & Fixed assets & Bond Yield \\
\hline Mean & 0,11 & 10097,49 & 2,10 & 986,20 & 4,99 & 45308,14 & 0,01 \\
\hline Median & 0,08 & 3162,63 & 1,41 & 728,35 & 2,58 & 6912,26 & 0,01 \\
\hline Maximum & 1,57 & 131454,30 & 62,23 & 4398,47 & 93,27 & 1538500,00 & 0,27 \\
\hline Minimum & $-0,67$ & 8,55 & $-48,66$ & 0,03 & $-82,11$ & 224,80 & $-0,18$ \\
\hline Std. Dev. & 0,23 & 21469,92 & 6,60 & 924,81 & 11,52 & 204110,60 & 0,07 \\
\hline Skewness & 2,13 & 3,72 & 1,67 & 1,06 & 0,35 & 6,85 & 0,09 \\
\hline Kurtosis & 14,08 & 17,70 & 50,15 & 3,94 & 32,83 & 48,67 & 3,92 \\
\hline Observations & 218 & 221 & 214 & 162 & 214 & 207 & 222 \\
\hline
\end{tabular}

\footnotetext{
${ }^{3}$ See the literature review in section 1.
} 
In the present paper, we decided to analyze three groups of determinants that can that can have theoretical relations with CDS. One group of determinants is composed of cash flow proxies such as working capital, retained earnings, EBIT, free cash flow, and free cash flow to the firm, and for those companies in the financial sector, we use the refinancing margin as a proxy for working capital. The second group is composed of proxies related to debt and tangibility such as property, plant, and equipment (PPE), total assets, total current liabilities, total debt to total assets, total liabilities, and total liabilities to book value, net debt, free cash flow to total debt, and total debt to tangible book value. Finally, the third group is comprised of those financial indicators that can act as a proxy for market expectations such as the bond yield of the previous year ${ }^{4}$. As a robustness check, we controlled for Standard and Poor's credit rating for each issue. All the issues in this paper have the same rating with the exception of two companies, and when we control for this effect, there is no significant change in the results obtained.

To control for endogeneity, we use a lagged panel regression model in the following form as described in Eq. 1:

$$
C D S_{i, t}=\alpha_{o}+\beta_{i, t-1} C F_{i, t-1}+\beta_{i, t-1} D E B T_{t-1}+\beta_{i, t-1} T A N_{t-1}+\beta_{i, t-1} M K T E_{t-1}+v_{i}+\varepsilon_{i, t}
$$

Where $C D S_{i, t}=$ is the credit default spread of a specific company, $C F_{t-1}=$ is a vector that contains all the financial indicators variables that are proxies for cash flow such as free cash flow, working capital, $E B I T$, and retained earnings. $D E B T_{t-1}=$ is a vector that contains proxies of debt such as current liabilities, total debt to total assets, net debt and free cash flow to total debt. $T A N_{t-1}=$ is vector that contains proxies of tangibility such as property, plant and equipment, total debt to tangible assets, inventories, total liabilities to tangible book value, and fixed assets to long-term investments. $M K T E_{t-1}=$ contains a proxy of market expectations which is the bond yield of the previous year, calculated as the annual variation of the weighted average market value portfolio of the total bonds issued by a specific company. Finally, $\mathrm{v}_{\mathrm{i}}$ and $\varepsilon_{i, t}$ are error terms that control for type of issuers and different time periods. All of the results presented have white diagonal corrected errors. Additionally, as we can see from table 2, we did Lagrange multiplier tests for random effects in order to check the robustness of our proposed specification, and in all four cases we rejected the null hypothesis that the no effect specification in our lagged model is adequate for the data analyzed:

\footnotetext{
${ }^{4}$ Although all of the companies in the sample trade their bonds on public markets, some of the companies in our sample do not have listed shares in any exchange, therefore, we cannot use the market capitalization or the last reported stock price as a proxy for market expectations.
} 
Langrage Multiplier Tests for Random Effects

Null hypotheses: A panel with no effects is adequate for the proposed panel regression.

Alternative hypotheses: A panel with company and year effects is adequate for the proposed panel regression.

\begin{tabular}{|c|c|c|c|}
\hline & \multicolumn{3}{|c|}{ Test Hypothesis } \\
\hline & Type of companies & Years & Both \\
\hline & & & \\
\hline \multirow[t]{2}{*}{ Breusch-Pagan } & $18.0439^{* * *}$ & $38.6189^{* * *}$ & $56.6629^{* * *}$ \\
\hline & $(0.0000)$ & $(0.0000)$ & $(0.0000)$ \\
\hline \multirow[t]{2}{*}{ Honda } & $4.2478^{* * *}$ & $6.2144^{* * *}$ & $7.3979^{* * *}$ \\
\hline & $(0.0000)$ & $(0.0000)$ & $(0.0000)$ \\
\hline \multirow[t]{2}{*}{ King-Wu } & $4.2478^{* * *}$ & $6.2144^{* * *}$ & $7.4436^{* * *}$ \\
\hline & $(0.0000)$ & $(0.0000)$ & $(0.0000)$ \\
\hline \multirow[t]{2}{*}{ Standardized Honda } & $6.2679^{* * *}$ & $7.8890^{* * *}$ & $5.4953^{* * *}$ \\
\hline & $(0.0000)$ & $(0.0000)$ & $(0.0000)$ \\
\hline \multirow[t]{2}{*}{ Standardized King-Wu } & $6.2679^{* * *}$ & $7.8890^{* * *}$ & $6.0849^{* * *}$ \\
\hline & $(0.0000)$ & $(0.0000)$ & $(0.0000)$ \\
\hline \multirow[t]{2}{*}{ Gourierioux, et al.* } & -- & -- & $56.6629^{* * *}$ \\
\hline & & & $(<0.01)$ \\
\hline & & & \\
\hline \multicolumn{4}{|c|}{ *Mixed chi-square asymptotic critical values: } \\
\hline $1 \%$ & 7.289 & & \\
\hline $5 \%$ & 4.321 & & \\
\hline $10 \%$ & 2.952 & & \\
\hline
\end{tabular}

Furthermore, from Table 2, we can observe that in the case of our panel regression, controlling for the type of companies and years under observation is the correct model specification for the data under analysis.

\section{EMPIRICAL RESULTS AND DISCUSSION}

When we used all the groups of common determinants (see Table 3), none of the groups of explanatory variables were statistically significant after we controlled for company and year effects. When we used all the groups of common determinants and divided the sample between public and private companies, we found that the only significant determinant group with significant explanatory variables was the tangibility group. For public companies, the significant variables were inventories and fixed assets, and for private companies, fixed assets were the only significant variable. For public companies, the only coefficient that had the expected economic sign was inventories (negative), and for private companies, the coefficient of fixed assets had the expected sign (negative). The only counterintuitive result was the coefficient of fixed assets in public companies that produced a positive sign. The economic significance of the findings are as follows: 1) An increase in fixed assets in a Latin American companies in a given year causes a CDS spread increase in the following year, the opposite happens for private companies, in which an increase in fixed assets causes a decrease in CDS spreads in the following year, 2) For public companies an increase in inventories in a previous year causes a decrease in CDS spreads in the following year. 
Therefore a public company in Latin America that reduces the amount of invested capital in fixed assets an inventories should improve its cost of insuring debt in the CDS market.

When we ran the regression using only one set of factors to explain the CDS variance (see Table 4), we found that for all of the companies, the only significant determinant was market expectations, and this determinant had the expected economic sign (negative). When we divided the sample between public and private companies, our group of determinants was only significant for public companies. For the cash flow determinants, the only significant explanatory variable was retained earnings, and this had the expected sign (negative). For the group of debt determinants, the only significant determinant was total debt/total assets, which had the correct sign for the coefficient (positive). For tangibility determinants, when we ran the regression with only one group of factors, the results obtained were similar to those obtained when we ran the regression with all the groups of determinants. This means that in the case of public companies in Latin America, tangibility is not as important as in other parts of the world, as the market for debt does not put significant value on the amount of physical collateral that a company has in any of the countries that confirm the region. This makes sense since a large part of the sample consists of public service companies; this means that in the case of a default, it would be almost impossible for a creditor to seize the assets of the company as collateral without facing the risk of nationalization by the home country. In summary, when we control for financial companies, the economic significance of the findings are as follows: 1) An increase in fixed assets in public Latin American companies in a given year causes a CDS spread increase in the following year, and the same occurs for private companies when we exclude financials from the sample, 2) For private companies without financials, an increase in total debt in a previous year causes a decrease in CDS spreads in the following year, although this result can be counterintuitive, it can be explained by the fact that a company that is able to raise more debt in international markets is perceived as a safer company for investors, 3) In the case of one set of determinants, such as the proxies for cash flows, an increase in retained earnings by public companies causes a decrease in CDS spreads. This makes sense because for a public company a higher amount retained earnings can be interpreted as market participants as a good signal of financial discipline, more liquidity and therefore this translates in lower CDS spreads as investors perceive less risk.

Table 3

Panel Regression estimates with all the companies in the sample

This panel reports the results of the panel regression $C D S_{i, t}=\alpha_{o}+\beta_{i, t-1} C F_{i, t-1}+\beta_{i, t-1} D E B T_{t-1}+\beta_{i, t-1} T A N_{t-1}+\beta_{i, t-1} M K T E_{t-1}+v_{i}+\varepsilon_{i, t}$ where $C D S_{i, t}$ is the CDS spread of any company $i$ at time $t$ from 2006 to $2016 . C F_{\mathrm{t}-1}=$ is a vector that contains all the lagged financial indicators variables that are proxies to cash flow such as free cash flow, working capital, EBIT, and retained earnings. $\mathrm{DEBT}_{\mathrm{t}-1}=$ is a vector that contains all the lagged proxies for debt such as current liabilities, total debt to total assets, net debt and free cash flow to total debt. TAN $\mathrm{T}_{\mathrm{t}-1}=$ is vector that contains all the lagged proxies of tangibility such as property, plant and equipment, total debt to tangible assets, inventories, total liabilities to tangible book value, and fixed assets to long-term investments. $\mathrm{MKTE}_{\mathrm{t}-1}=$ is a lagged proxy for market expectations, which is the bond yield of the previous year, calculated as the annual variation in the weighted average market value portfolio of the total bonds issued by a specific company. In this set of regressions, we use all the companies in the sample including financial services. 


\begin{tabular}{|c|c|c|c|c|c|c|}
\hline Dependent variable CDS & $\begin{array}{c}\text { All } \\
\text { companies }\end{array}$ & Public & Private & $\begin{array}{c}\text { All } \\
\text { companies } \\
\text { one set of } \\
\text { factors }\end{array}$ & $\begin{array}{c}\text { Public } \\
\text { companies one } \\
\text { set of factors }\end{array}$ & $\begin{array}{c}\text { Private } \\
\text { companies } \\
\text { one set of } \\
\text { factors }\end{array}$ \\
\hline \multicolumn{7}{|l|}{ Cash flow } \\
\hline \multirow[t]{2}{*}{ Free cash flow t-1 $_{1}$} & $-3,6707$ & 2,4412 & 2,3507 & $-0,0010$ & $-0,0006$ & 0,0056 \\
\hline & $(3,9472)$ & $(2,2972)$ & $(8,8903)$ & $(0,0053)$ & $(0,0035)$ & $(0,0107)$ \\
\hline \multirow{2}{*}{ Working capital $l_{t-1}$} & $-3,5114$ & 0,7232 & $-6,8212$ & $-0,0083$ & $-0,0067$ & $-0,0087$ \\
\hline & $(2,9843)$ & $(1,2627)$ & $(11,4316)$ & $(0,0056)$ & $(0,0066)$ & $(0,0085)$ \\
\hline \multirow[t]{2}{*}{ Ebit $t_{t-1}$} & 0,0834 & $-18,8102$ & 15,3275 & $-0,0099$ & 0,0310 & $-0,0257$ \\
\hline & $(9,4864)$ & $(28,3465)$ & $(24,4046)$ & $(0,0121)$ & $(0,0579)$ & $(0,0236)$ \\
\hline \multirow[t]{2}{*}{ Retained Earnings $s_{t-1}$} & $-24,4616$ & $-22,8440$ & $-69,1867$ & $-0,0470$ & $-0,0707 *$ & 0,0430 \\
\hline & $(28,0786)$ & $(22,2251)$ & $(84,6324)$ & $(0,0419)$ & $(0,0387)$ & $(0,0899)$ \\
\hline \multicolumn{7}{|l|}{$\underline{D e b t}$} \\
\hline \multirow[t]{2}{*}{ Current liabilitiest-1 } & $-1,2750$ & 23,9645 & $-14,0370$ & 0,0308 & 0,0389 & $-0,0032$ \\
\hline & $(42,4098)$ & $(39,7019)$ & $(273,4767)$ & $(0,1075)$ & $(0,1101)$ & $(0,2915)$ \\
\hline \multirow[t]{2}{*}{ Total debt/Total assets t-1 $_{1}$} & $-110,1829$ & 118,9510 & 1643,8930 & 0,1279 & $1,1161^{* *}$ & $-0,5782$ \\
\hline & $(250,9158)$ & $(255,7639)$ & $(933,8764)$ & $(0,4994)$ & $(0,5549)$ & $(0,8847)$ \\
\hline \multirow[t]{2}{*}{ Net debt $t_{t-1}$} & $-6,8557$ & 1,3274 & 264,0249 & 0,0081 & 0,0033 & 0,3050 \\
\hline & $(4,5425)$ & $(4,3112)$ & $(279,3878)$ & $(0,0104)$ & $(0,0090)$ & $(0,6501)$ \\
\hline \multirow[t]{2}{*}{ Free cash flow/Total debt $t_{t-1}$} & 76,8442 & $-23,1185$ & 27,1556 & $-0,1782$ & $-0,0997$ & 0,1855 \\
\hline & $(116,6246)$ & $(106,2238)$ & $(651,9002)$ & $(0,1296)$ & $(0,0917)$ & $(0,5837)$ \\
\hline \multicolumn{7}{|l|}{ Tangibility } \\
\hline \multirow[t]{2}{*}{ Property, plant and equipment $t_{t-1}$} & 2,8607 & 4,8989 & $-91,3016$ & 0,2299 & $-1,0128$ & 84,4944 \\
\hline & $(77,1881)$ & $(53,3269)$ & $(179,1465)$ & $(0,2103)$ & $(42,8536)$ & $(153,1996)$ \\
\hline \multirow[t]{2}{*}{ Total debt/Total tangible assets t- $_{1}$} & $-33,7980$ & $-49,3462$ & $-7,4029$ & 0,0985 & $-30,6376$ & 10,3655 \\
\hline & $(30,9166)$ & $(34,8445)$ & $(56,9862)$ & $(0,1012)$ & $(21,3740)$ & $(61,1219)$ \\
\hline \multirow[t]{2}{*}{ Inventories $_{t-1}$} & 15,0498 & $-46,3496^{*}$ & $-159,3925$ & $-0,0287$ & $-42,1841 * *$ & $-125,1880$ \\
\hline & $(32,8263)$ & $(26,8516)$ & $(313,9005)$ & $(0,1412)$ & $(20,2673)$ & $(101,5549)$ \\
\hline \multirow[t]{2}{*}{ Total liabilities to tangible assets $_{t-1}$} & 22,0053 & 30,2358 & 8,2832 & $-0,0579$ & 18,6979 & $-2,6039$ \\
\hline & $(19,6459)$ & $(20,0484)$ & $(37,2398)$ & $(0,0643)$ & $(12,5677)$ & $(39,7098)$ \\
\hline \multirow[t]{2}{*}{ Fixed assets $t_{t-1}$} & $-0,0015$ & $0,0059 * *$ & $-0,0078^{*}$ & 0,0000 & $0,0040 * * *$ & $-0,0024$ \\
\hline & $(0,0032)$ & $(0,0029)$ & $(0,0040)$ & $(0,0000)$ & $(0,0014)$ & $(0,0036)$ \\
\hline \multicolumn{7}{|l|}{ Market expectations } \\
\hline \multirow[t]{2}{*}{ Bond yield $t-1$} & $-183,3446$ & 57,7636 & $-928,4421$ & $-1,2627^{*}$ & $-79,6180$ & $-1,9244$ \\
\hline & $(230,6768)$ & $(120,2234)$ & $(958,8655)$ & $(0,6647)$ & $(112,3073)$ & $(1,6158)$ \\
\hline Adjusted $\mathrm{R}^{2}$ & 0,8450 & 0,8297 & 0,9758 & $\begin{array}{c}0,8215- \\
0,8515\end{array}$ & $0,8893-0,9338$ & $0,7657-0,8585$ \\
\hline Number of observations & 120 & 77 & 43 & $115-164$ & $77-109$ & $44-55$ \\
\hline YearEffects & YES & YES & YES & YES & YES & YES \\
\hline Company effects & YES & YES & YES & YES & YES & YES \\
\hline
\end{tabular}


Panel Regression estimates with all the companies without financials

This panel reports the result of the panel regression $C D S_{i, t}=\alpha_{o}+\beta_{i, t-1} C F_{i, t-1}+\beta_{i, t-1} D E B T_{t-1}+\beta_{i, t-1} T A N_{t-1}+\beta_{i, t-1} M K T E_{t-1}+v_{i}+\varepsilon_{i, t}$ where $C D S_{i, t}$ is the CDS spread of any company $i$ at time $t$ from 2006 to $2016 . C F_{\mathrm{t}-1}=$ is a vector that contains all the lagged financial indicators variables that are proxies to cash flow such as free cash flow, working capital, EBIT, and retained earnings. $\mathrm{DEBT}_{\mathrm{t}-1}=\mathrm{is}$ a vector that contains all the lagged proxies for debt such as current liabilities, total debt to total assets, net debt and free cash flow to total debt. TAN $\mathrm{t}_{\mathrm{t}-1}=$ is vector that contains all the lagged proxies of tangibility such as property, plant and equipment, total debt to tangible assets, inventories, total liabilities to tangible book value, and fixed assets to long-term investments. $\mathrm{MKTE}_{\mathrm{t}-1}=$ is a lagged proxy for market expectations, which is the bond yield of the previous year, calculated as the annual variation in the weighted average market value portfolio of the total bonds issued by a specific company. In this set of regressions, we use all the companies in the sample without financials services.

\begin{tabular}{|c|c|c|c|c|c|c|}
\hline Dependent variable CDS & $\begin{array}{c}\text { All } \\
\text { companies } \\
\text { without } \\
\text { financials }\end{array}$ & $\begin{array}{c}\text { Public } \\
\text { companies } \\
\text { without } \\
\text { financials }\end{array}$ & $\begin{array}{c}\text { Private } \\
\text { companies } \\
\text { without } \\
\text { financials }\end{array}$ & $\begin{array}{c}\text { All } \\
\text { companies } \\
\text { without } \\
\text { financials } \\
\text { one set of } \\
\text { factors }\end{array}$ & $\begin{array}{c}\text { Public } \\
\text { companies } \\
\text { without } \\
\text { financials } \\
\text { one set of } \\
\text { factors }\end{array}$ & $\begin{array}{c}\text { Private } \\
\text { companies } \\
\text { without } \\
\text { financials one } \\
\text { set of factors }\end{array}$ \\
\hline \multicolumn{7}{|l|}{ Cash flow } \\
\hline \multirow[t]{2}{*}{ Free cash flowt } & 0,0008 & 0,0103 & 0,0211 & 0,0003 & 0,0012 & 0,0056 \\
\hline & $(0,0137)$ & $(0,0115)$ & $(0,0401)$ & $(0,0084)$ & $(0,0068)$ & $(0,0107)$ \\
\hline \multirow[t]{2}{*}{ Working capital $l_{t-1}$} & $-0,0027$ & 0,0046 & $-0,0093$ & $-0,0075$ & $-0,0051$ & $-0,0087$ \\
\hline & $(0,0096)$ & $(0,0068)$ & $(0,0438)$ & $(0,0061)$ & $(0,0060)$ & $(0,0085)$ \\
\hline \multirow[t]{2}{*}{$\overline{\text { Ebit } t-1}$} & $-0,0008$ & 0,0196 & 0,0100 & $-0,0105$ & 0,0397 & $-0,0257$ \\
\hline & $(0,0315)$ & $(0,1044)$ & $(0,1188)$ & $(0,0130)$ & $(0,0767)$ & $(0,0236)$ \\
\hline \multirow[t]{2}{*}{ Retained Earnings $s_{t-1}$} & $-0,0425$ & $-0,0700$ & $-0,0270$ & $-0,0422$ & $-0,1056^{*}$ & 0,0430 \\
\hline & $(0,0888)$ & $(0,0808)$ & $(0,3947)$ & $(0,0549)$ & $(0,0549)$ & $(0,0899)$ \\
\hline \multicolumn{7}{|l|}{$\underline{D e b t}$} \\
\hline \multirow[t]{2}{*}{ Current liabilitiest-1 } & $-0,0020$ & 0,0935 & 0,8277 & 0,0581 & 0,0529 & $-0,0032$ \\
\hline & $(0,1323)$ & $(0,1567)$ & $(0,9721)$ & $(0,1118)$ & $(0,1124)$ & $(0,2915)$ \\
\hline \multirow[t]{2}{*}{ Total debt/Total assets } & $-0,1450$ & 1,1251 & $-8,4847 *$ & 0,0252 & $1,2592^{*}$ & $-0,5782$ \\
\hline & $(0,8999)$ & $(1,1643)$ & $(4,6679)$ & $(0,5191)$ & $(0,6874)$ & $(0,8847)$ \\
\hline \multirow[t]{2}{*}{ Net debtt-1 } & $-0,0020$ & 0,0098 & 1,6438 & $-0,0064$ & $-0,0019$ & 0,3050 \\
\hline & $(0,0177)$ & $(0,0165)$ & $(1,3786)$ & $(0,0132)$ & $(0,0081)$ & $(0,6501)$ \\
\hline \multirow[t]{2}{*}{ Free cash flow/Total debt } & $-0,3307$ & $-0,2656$ & 1,5879 & $-0,2142$ & 0,0150 & 0,1855 \\
\hline & $(0,4468)$ & $(0,4779)$ & $(2,4626)$ & $(0,3093)$ & $(0,2230)$ & $(0,5837)$ \\
\hline \multicolumn{7}{|l|}{ Tangibility } \\
\hline Property, plant and equipment t-1 & 0,0969 & $-0,0274$ & $-0,6458$ & 0,2299 & $-0,0681$ & 0,3726 \\
\hline
\end{tabular}




\begin{tabular}{|c|c|c|c|c|c|c|}
\hline & $(0,2524)$ & $(0,2416)$ & $(0,6665)$ & $(0,2103)$ & $(0,1886)$ & $(0,4478)$ \\
\hline \multirow[t]{2}{*}{ Total debt/Total tangible assetst-1 } & $-0,0056$ & $-0,1535$ & 0,0622 & 0,0985 & $-0,0156$ & 0,1277 \\
\hline & $(0,0916)$ & $(0,1510)$ & $(0,2312)$ & $(0,1012)$ & $(0,1092)$ & $(0,1642)$ \\
\hline \multirow[t]{2}{*}{ Inventoriest-1 } & 0,0804 & $-0,1664$ & $-1,4946$ & $-0,0287$ & $-0,1858^{*}$ & $-0,1801$ \\
\hline & $(0,1386)$ & $(0,1361)$ & $(1,1298)$ & $(0,1412)$ & $(0,1065)$ & $(0,2844)$ \\
\hline \multirow[t]{2}{*}{ Total liabilities to tangible assetst-1 } & 0,0055 & 0,0986 & $-0,0314$ & $-0,0579$ & 0,0167 & $-0,0759$ \\
\hline & $(0,0566)$ & $(0,0865)$ & $(0,1427)$ & $(0,0643)$ & $(0,0639)$ & $(0,1070)$ \\
\hline \multirow[t]{2}{*}{ Fixed assetst } & 0,0000 & $0,0000^{* *}$ & 0,0000 & 0,0000 & $0,0000^{* * * *}$ & 0,0000 \\
\hline & $(0,0000)$ & $(0,0000)$ & $(0,0000)$ & $(0,0000)$ & $(0,0000)$ & $(0,0000)$ \\
\hline \multicolumn{7}{|l|}{ Market expectations } \\
\hline \multirow[t]{2}{*}{ Bond yieldt-1 } & $-0,8972$ & 0,2990 & $-7,2147$ & $-413,4842$ & $-0,3575$ & $-563,4308$ \\
\hline & $(0,8995)$ & $(0,6385)$ & $(4,8707)$ & $(285,7003)$ & $(132,5523)$ & $(634,0142)$ \\
\hline Adjusted $\mathrm{R}^{2}$ & 0,8264 & 0,8683 & 0,7846 & $\begin{array}{c}0,7278- \\
0,8397\end{array}$ & $\begin{array}{c}0,8360- \\
0,8795\end{array}$ & $0,7125-0,7952$ \\
\hline Number of observations & 120 & 77 & 43 & $121-135$ & $77-80$ & $44-45$ \\
\hline Year effects & YES & YES & YES & YES & YES & YES \\
\hline Company effects & YES & YES & YES & YES & YES & YES \\
\hline
\end{tabular}

To check for robustness, we ran the regression without including financial firms and found that for all the companies in the sample, none of the groups of explanatory variables were statistically significant after we controlled for company and year effects. When we divide the sample between public and private companies, we observed that the only significant explanatory variable was fixed assets for public companies and total debt/assets for private companies. When we run the regression with just one group of determinants, we found that for private companies, none of the explanatory variables were significant, but for public companies, the results obtained were the same as with the sample including financial companies. This means that in both cases, for the cash group of determinants, retained earnings is statistically significant and has the correct sign, and for the debt group, the significant determinant is total debt over assets, and for the tangibility group, it is inventories and fixed assets. In all cases, the coefficients have the same sign as in the sample that included financial companies. For the sample of private companies without financials, when we ran the regression with one set of factors, the results were the same as in the previous case.

\section{CONCLUSION}

In this paper, we analyzed the effects of common corporate debt determinants and their effects on CDS spreads. We found that in order to determine the statistically significant effects for the Latin American CDS spread determinants, it was necessary to control for the type of ownership. For public companies with and without financials in the sample, the results are robust for certain types of proxies for cash, debt, and tangibility. The significant proxies for public companies are retained earnings, total debt/assets, inventories, and fixed assets. For private companies, the results change when we control the sample for financial companies, as when we use all the private companies in the sample, the only meaningful proxy for tangibility is fixed assets, and when we exclude financials, the only meaningful proxy for debt is total debt/total assets. Our results are in line with a recent study by by Huang \& Petkevich (2016), in which the authors studied the effect of corporate ownership on bond spreads. Our results show 
that for the Latin American region, the type of ownership can play an important role, since the common determinants for CDS spreads used in the literature can help explain the variation in public companies, but these determinants have no major statistically significant effects on private companies.

\section{ACKNOWLEDGEMENT}

The authors are thankful to CESA Business School for the financial support needed to carry out this research.

\section{REFERENCES}

Altman, E. I. (2005). An emerging market credit scoring system for corporate bonds. Emerging Markets Review, 6(4), 311-323.

Balazs, C., \& Ivaschenko, I. (2013). Determinants of Sovereign Bond Spreads in Emerging Markets: Local Fundamentals and Global Factors vs. Ever-Changing Misalignments. IMF working papers, 1-41.

Bekaert, G., \& Harvey, C. R. (1997). Emerging Equity Market Volatility. Journal of Financial Economics, 43(1), 29-77. doi: http://www.elsevier.com/wps/find/journaldescription.cws_home/505576/description\#description

Calvo, S., \& Reinhart, C. M. (1999). Capital Flows to Latin America: Is There Evidence of Contagion Effects? The World Bank, Policy Research Working Paper Series: $1619 . \quad$ Retrieved from http://econ.worldbank.org/files/13465_wps1619.pdf

Che-Yahya, N., Abdul-Rahim, R., \& Mohd-Rashid, R. (2016). Determinants of Corporate Bond Yield: The Case of Malaysian Bond Market. International Journal of Business and Society, 17(2), 245.

Dittmar, R. F., \& Yuan, K. (2008). Do Sovereign Bonds Benefit Corporate Bonds in Emerging Markets? Review of Financial Studies, 21(5), 1983-2013. doi: http://rfs.oxfordjournals.org/content/by/year

Douglas, A. V., Huang, A. G., \& Vetzal, K. R. (2016). Cash flow volatility and corporate bond yield spreads. Review of Quantitative Finance and Accounting, 46(2), 417-458.

Dungey, M., Fry, R., Gonzalez-Hermosillo, B., \& Martin, V. L. (2005). Empirical Modelling of Contagion: A Review of Methodologies. Quantitative Finance, 5(1), 9-24. doi: http://www.tandf.co.uk/journals/titles/14697688.asp

Edwards, S. (1986). The pricing of bonds and bank loans in international markets: An empirical analysis of developing countries' foreign borrowing. European Economic Review, 30(3), 565-589. doi: http://dx.doi.org/10.1016/0014-2921(86)90009-7

Eichengreen, B., \& Mody, A. (1998). What explains changing spreads on emerging-market debt: fundamentals or market sentiment? : National Bureau of Economic Research.

Erb, C. B., Harvey, C. R., \& Viskanta, T. E. (1999). New Perspectives on Emerging Market Bonds. Journal of Portfolio Management, 25(2), 83-92.

Ferrucci, G. (2003). Empirical determinants of emerging market economies' sovereign bond spreads. Bank of England (205), 1-42.

Fuertes, A., Lamas, M., de la Peña, E. M., \& Romo, L. (2016). Tendencias globales de financiación en los mercados de capitales en 2015. Boletín Económico, 2.

Ge, W., \& Kim, J.-B. (2014). Real earnings management and the cost of new corporate bonds. Journal of Business Research, 67(4), 641-647.

Ge, W., \& Liu, M. (2015). Corporate social responsibility and the cost of corporate bonds. Journal of Accounting and Public Policy, 34(6), 597-624.

Hammami, Y., \& Bahri, M. (2016). On the determinants of expected corporate bond returns in Tunisia. Research in International Business and Finance, 38, 224-235.

Hotchkiss, E. S., \& Jostova, G. (2007). Determinants of corporate bond trading: A comprehensive analysis.

Huang, K., \& Petkevich, A. (2016). Corporate bond pricing and ownership heterogeneity. Journal of Corporate Finance, 36, 54-74.

Martinez, L. B., Terceño, A., \& Teruel, M. (2013). Sovereign bond spreads determinants in Latin American countries: Before and during the XXI financial crisis. Emerging Markets Review, 17, 60-75. doi: 10.1016/j.ememar.2013.08.004 
Massa, M., \& Žaldokas, A. (2014). Investor base and corporate borrowing: Evidence from international bonds. Journal of International Economics, 92(1), 95-110.

Pieterse-Bloem, M., Qian, Z., Verschoor, W., \& Zwinkels, R. (2016). Time-varying importance of country and industry factors in European corporate bonds. Journal of Empirical Finance, 38, 429-448.

Rajan, R. G., \& Zingales, L. (1995). What do we know about capital structure? Some evidence from international data. The Journal of Finance, 50(5), 1421-1460.

Reinhart, C. M., \& Rogoff, K. S. (2008). This time is different: A panoramic view of eight centuries of financial crises: National Bureau of Economic Research.

Šević, A., \& Lu, J. (2013). Determinants of corporate bond yield in china. ekonomske te ekonomske teme, 51(3), 425-440.

Van Landschoot, A. (2008). Determinants of yield spread dynamics: Euro versus US dollar corporate bonds. Journal of Banking \& Finance, 32(12), 2597-2605.

Nguyen, S., \& Wolfee, S. (2016). Determinants of successful access to bank loans by Vietnamese SMEs: new evidence from the red river delta. Journal of Internet Banking and Commerce, 21(1), 1-23. 